\title{
THE BALANCE AMONG QUALITY, SCALE AND EFFECTIVENESS- AN EMPIRICAL STUDY ON SCALE EFFECT IN TEACHING VENUES AT PREFECTURE AND CITY LEVEL OF RADIO \& TV UNIVERSITIES IN CHINA
}

\author{
Li Ying, Zhang Xuhong, Li Ruiqing, Chen Haishan, \& Zhang Shaogang \\ China Central Radio \& TV University \\ ly@crtvu.edu.cn
}

\begin{abstract}
Teaching venues are playing an important role in the filed of open and distance education (ODL). In China's ODL system over 70\% enrolled students are from Radio and TV Universities (RTVUS). Many off-campus teaching venues of e-colleges in 67 conventional universities have been established in RTVUs at prefecture and city level. In this article, the authors have done a direct survey on the data of distance education cost over the past consecutive 4 years in 21 RTVUs at prefecture and city level from 3 provinces (Xinjiang, Hunan and Fujian) in China's western, central and eastern areas, and empirically studied the scale effect in teaching venues at prefecture and city level under the hypothesis condition-teaching effect of ODL and conventional education is the same. The study result illustrates that the average student cost of RTVUs at prefecture and city level demonstrates a scale economy feature, that is, with the expansion of enrolled students scale, there is a fall in the average student cost. The study indicates large differences between average student variable cost and average student cost, which shows a possible average cost reduction in RTVUs at prefecture and city level. In terms of geographical and economic differences, some imbalances of development have been found among RTVUs at prefecture and city level. A quadratic form regression model has been established for doing this research in the perspective of education economics. The results of the regression show that the optimal enrolled student number of RTVUs nationwide at prefecture and city level is around 7,800. For provinces, the most optimal enrolled student numbers are as follows: 9,100 for Fujian, 3,800 for Hunan, and 2,200 for Xianjiang, which can serve as the reference for expanding scale economy in ODL. The research finding also indicate the changes in student average cost resulting from the changes in scale, the problem of determining investment direction. It is suggested that more input which benefit the quality improvement of distance education should be made.
\end{abstract}

Keyword: Open and distance learning, RTVUs, education economics, scale economy, teaching venues, off-campus teaching venues. 
The important economic characteristic of modern distance education is based on the expansion in student number and the sharing of relatively high fixed cost in order to offer education service of low cost but high quality by reducing the variable cost.

Since China has implemented "National Modern Distance Education Engineering" in 1998. NICE (Ministry of Education) launched "CCRTVU: Developing New Ways to Cultivate People of Talents and the Open Education Pilot Project (1999-2007)". The "Open Learning" has been developing vigorously, the accumulated number of student enrolment in RTVUs and the value of fixed assets has been increased greatly and broken history record. The development of RTVUs has reached a new high. As one of the biggest distance higher education institutions, RTVUs are also facing new challenges: What about the average variable cost per student in the new period? What's the relationship between the average variable cost per student and the number of students? Whether there is an upper and lower limit for running-school scale? How to keep the balance of quality, scale and effectiveness? All the questions mentioned above are facing China's ODL and ODL in populous developing countries. 'These questions are research topics on distance education economics to be explored.

The most significant characteristic of ODL implementation is its systematic organization. RTVUs system is composed of 1 CCRTVU (China Central Radio \& TV University), 44 provincial Radio and TV Universities, 956 RTVUs at prefecture and city level, 1,875 study centers at county and city level, and $86.1 \mathrm{k}$ full time staff and $36.1 \mathrm{~K}$ part time staff work for this multi-layered RTVUs system (CCRTV, 2007). Each level plays different roles and undertakes different tasks in cultivating students in ODL system. Because RTVUs at local level are under the administration of local governments and have teen established separately or jointly, they usually adopt independent costing procedures. Generally speaking, RTVUs at local level have their own costing systems respectively.

In 'Empirical and Comparative Study of Cost Efficiency in RTVUs', a direct survey on the data of distance education cost covering the past consecutive 4 years in 21 RTVUs at prefecture and city level from 3 provinces in China western, central and eastern area, has been done. This survey is to review the scale economy of ODL in RTVUs at prefecture and city level in the aspects of the average cost per student, the average variable cost per student, the scale economy and optimal economic scale of student number and etc.

\section{THEORETICAL BACKGROUND}

The earliest classic study on the scale economy of distance education shall be traced back to Wagner's research findings (Wagner, 1972, 1973, 1977) in 1970s. In 1972, Wagner made a cost comparison between the budget data of OU (Open University in U.K) in 1973 and the actual cost data of conventional higher education institution in U.K. in 1969. Wagner's research findings are: each equivalent student cost for open education 1/4 of conventional student average cost. If on-job students, cost in OU calculated as $50 \%$ of the full-time students cost in conventional university and include research done in conventional universities, the adjusted OU student average cost is about $69,1 \%$ of that of conventional university student. Although Wagner himself prefers to using the rate of $1 / 4$ to explain the cost-effectiveness ref open university, but another distance learning expert Grenville Rumble (Rumble, 1997) 
believes that the result of $69.1 \%$ is closer to the fact. Wagner's research finding in 1977 further reveals: with the increasing number of OU students, OU has obtained economic benefit from the scale expansion, i.e. scale economy. Greville Rumble's research (Rumble, 1976) shows: the OU full-time equivalent student average cost is $41 \%$ of that of conventional university students. After that, more data and evidence for the comparison of average student cost between students from distance education institutions and conventional universities have been collected in different countries. A cross nation research in 1991 shows, the ratio of the average student cost between the students loom distance education institutions which have been independently established and conventional universities in Pakistan, China (China Radio and TV Universities) and Korea is $0.22,0.50$ and 0.10 respectively. Moreover, a research conducted in India in 1993 indicates that the ratio of the average student cost between independently established distance education institutions and conventional universities is between 0.08-0.41 (Rumble, 1997).

The domestic research on distance learning scale economy started since 1990s. The influential research findings as follows: Xingyi: he has found out-4lk learners watching educational TV programs at same time can help the institution to achieve the break even point in satellite based education. Ding Xingfu research on the investment benefit based on China RTVUs, he points out that there shall be upper limit for quality control and a lower limit. otherwise effectiveness cannot be achieved; Wu Gengsheng and Li Haixia's case study based on Tsinghua University e-college, they find out that cost of online education is much lower than the conventional education; Zheng Qinhua and Chen Li's analysis on the operation of a e-college in a certain university and the online courses operation cost status, 388 learner can help institution to achieve the break even point; and Yang Tingting and Yin Shuangxu's research on the benefit of for multi-media teaching material construction of Radio and TV University, they find out that the student number for reaching break even point of various media teaching materials is from 1600 to 10000; student number for break even point of courses is 5632: the cycle for reaching break even point is 3 years; student number of specialty (degree) for break even point is 5989 , and cycle for specialty is 5 years and etc. The above researches have explored the cost-effectiveness problem of distance learning in China from different angles, and have made significant contributions to the latter researchers to make further and deeper research do this field. However, how to penetrate into economics analysis in an ever more strict sense from cost \& revenue analysis to accounting case study and descriptive statistics research and study? How to establish regression model based on economic theory, make statistic and reasoning, offer threshold value for reference? The economic analysis for ODL in the new era of web-based RTVUs is even more crucial, which is determined by the role of RTVUs is in the development of distance education in China. As a result, to collect data based on RTVUs, use economic model and economics methods to analyze the cost-effectiveness of distance learning, provide new evidence for the open education scale-economy of RTVUs in the new century are of great theoretical and practical significance for the understanding of cost-effectiveness status of distance education in China.

To do research on the cost-effectiveness of distance learning, the general hypothesis is education effect of the distance and conventional education is the same and such a hypothesis has been adopted in this paper for research purpose. 


\section{METHODS}

Panel data has been used in this research paper. The characteristic of panel data is that it includes time sequence information. The data used in thus research is collected through two methods. One is to get the relevant data from China Statistics Yearbook and the RTVUs Education Yearbook; the other is to directly survey accounting and costing data on open education of sample RTVUs at prefecture and city level from 2002-2005. Components covered in costing data is based on the budget accounting items for public institutions in China and our prior research findings-Major parameters of cost system, There are 4 major cost parameter fixed assets cost, human resources cost, study resources cost, and management cost, and 33 sub-cost parameter.

Survey samples for the research are selected according to the characteristic of Chinas different economic development levels in three different areas-East, Middle and West, and only one province is selected from each of the three areas. Teaching venues samples are selected from RTVUs at prefecture and city level from the chosen provinces. Cost data in 4 consecutive years in one teaching venues in RTVUs it prefecture and city level have been obtained and 21 teaching venues have been involved in the survey, which takes up $47 \%$ of the total number of teaching venues at prefecture and city level in Fujian, Hunan and Xinjiang.

The research methods for data processing and analyzing in based on Eviews software, such as statistics description, construction of regression function and quadratic function have been adopted in the research. The statistics description method is for the average cost per student from RTVUs at prefecture and city level. The average variable cost per student is calculated by

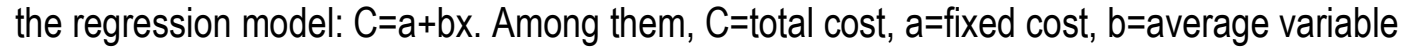
cost per student, $x=$ number of enrolled students.

The conventional education scale-economy research model in China (Ding Xiaohao, 2000) has been applied to the research on scale economy of RTVUs and the optimal scale in student number. The econometric model of thus research is setup as $U$ shaped quadratic function form, i.e.

ACit $=a i+b^{*}$ Sit $+c^{*}$ SRit $+d^{*}$ STRit $+e^{*}$ Dit $+u$ it, $i=1,2 \ldots 21 ; t=1,2,3,4$

ACit: the average cost per student

Sit: enrolled students number

SRit: the square of the enrolled student member

STRit: the ratio between students and teachers (Calculated by enrolled student number/full time tutors and part-time tutors)

Dit: the regional dummy variables (apply to national samples only, not for provincial samples)

The function stands for taking the average cost per student as the explained variable, the enrolled students number, the square of enrolled student number, ratio between teachers and students, regional dummy variable as the explanatory variable (western areas as the benchmark) to set up $U$ shaped regression model to figure out the optimal scale. 
During data processing, the cost value has been balanced and deducted by local consuming price index.

In this paper, these are 3 core research contents: cost per students, variable cost per students, scale economy analysis and the optimal enrolled student's number. Research based on national and provincial data have been done respectively for each of the research content. It is believed that not only information on the development of nationwide RTVUs at prefecture and city level, but also the detailed development information on the selected samples from Fujian, Hunan and Xinjiang can be obtained in doing so. More importantly, the 3 provinces can serve as the representatives of the 3 economic development zones in the east, central and west in China. From the local situation of development in the 3 provinces, the general information of RTVUs at prefecture and city level in the 3 different economic development zones can be worked out.

During the cost survey, we notice that are diversified programmes of running-school in RTUVs at prefecture and city level. The students recruited include open learning students, non-degree students, registered audio \& visual students, secondary \& vocational students and non-degree students and etc. Consequently, we need to split the actual cost of students involved in ODL from the originally obtained data. Through both the statistic of assessment data by experts of ODL project and consultation, we define the cost coefficient after splitting is 0.75 . In this way, the results of empirical research form both original data and adjust data have been reported in this paper to make convincible and quality research findings.

\section{RESULT AND DISCUSSION}

\section{The Average Cost per Student from RTVUs at Prefecture and City Level}

With the expansion in enrolled student number the average cost per student from RTVUs at prefecture and city level drops. This finding applies to both national and provincial samples. Refer to Table 1 (the original data) and Table 2 (the adjusted data by coefficient).

Table 1. Average Cost per Student from RTVUs at Prefecture and City Level (Unchanged Price, Unit: RMB Yuan)

\begin{tabular}{ccccccccc}
\hline \multirow{2}{*}{ Year } & \multicolumn{3}{c}{ Averaged Value for the Average Cost per St } & \multicolumn{3}{c}{ Average Enrolled St Number } \\
\cline { 2 - 9 } & $\begin{array}{c}\text { Nationwide } \\
(21)\end{array}$ & $\begin{array}{c}\text { Fujian } \\
(10)\end{array}$ & $\begin{array}{c}\text { Hunan } \\
(6)\end{array}$ & $\begin{array}{c}\text { Xinjiang } \\
(5)\end{array}$ & $\begin{array}{c}\text { Nationwide } \\
(21)\end{array}$ & $\begin{array}{c}\text { Fujian } \\
(10)\end{array}$ & $\begin{array}{c}\text { Hunan } \\
(6)\end{array}$ & Xinjiang \\
& 3178 & 1687 & 4852 & 4152 & 2335 & 3426 & 1396 & 1278 \\
2002 & 2091 & 1400 & 2532 & 2944 & 3359 & 4639 & 2719 & 1563 \\
2003 & 1920 & 1272 & 2655 & 2335 & 4012 & 5234 & 3533 & 2142 \\
2004 & 2100 & 1648 & 2241 & 2834 & 3906 & 4874 & 3954 & 1912 \\
2005 & 2322 & 1502 & 3070 & 3066 & 3403 & 4543 & 2901 & 1724 \\
$2002-2005$ & 2303 &
\end{tabular}

Note: $\quad$ a. Enrolled ST Number = Enrolled non-degree + enrolled degree

b. (cases number)

c. original costing data

d. Unchanged price $=100^{*}$ current year cost/local CPI

Table 1 and Table 2 indicate that different economic development level in China makes a development imbalance in RTVUs at prefecture and city level-for enrolled students' number: 
keep failing from east to west, as for average cost per student. RTVU in Fujian has the lowest, while RTVUs in Hunan and Xinjiang are close in cost per student.

Table 2. Average Cost per Student from RTVUs at Prefecture and City Level (Unchanged Prices, Unit: RMB Yuan)

\begin{tabular}{ccccccccc}
\hline Year & \multicolumn{2}{c}{ Averaged Value for the Average Cost per St } & \multicolumn{4}{c}{ Average Enrolled St Number } \\
\hline & Nationwide & Fujian & Hunan & Xinjiang & Nationwide & Fujian & Hunan & Xinjiang \\
& $(21)$ & $(10)$ & $(6)$ & $(5)$ & $(21)$ & $(10)$ & $(6)$ & $(5)$ \\
\hline 2002 & 2384 & 1265 & 3639 & 3114 & 2335 & 3426 & 1396 & 1278 \\
2003 & 1568 & 1050 & 1899 & 2208 & 3359 & 4639 & 2719 & 1563 \\
2004 & 1440 & 954 & 1991 & 1751 & 4012 & 5234 & 3533 & 2142 \\
2005 & 1575 & 1236 & 1681 & 2126 & 3906 & 4874 & 3954 & 1912 \\
$2002-2005$ & 1742 & 1127 & 2303 & 2300 & 3403 & 4543 & 2901 & 1724 \\
\hline
\end{tabular}

Note: $\quad$ a. Enrolled ST Number $=$ Enrolled non-degree + enrolled degree

b. (cases number)

c. Adjusted data hl' coefficient, cost coefficient $=0.75$

d. Unchanged price $=100^{*}$ current Year cost/local CPI

The Average Variable Cost per Student from RTVUs at Prefecture and City Level The findings of regression model shows that the regression coefficient of enrolled student number is 0.046015 (national), 0.029315 (Fujian). 0.079082 (Hunan), and 0.0137426 (Xinjiang), which indicates that the average variable cost per student from RTVUs at prefecture and city level is 460 RMB (national), 293 (Fujian), 791 (Hunan), 1374 (Xinjiang) (see table 3). Compared with Table 1, it has been found out that there is still a big gap between the average variable cost per student and the average cost per student from RTVUs at prefecture and city level. It shows that there is still room for RTVUs at prefecture and city level to reduce the average student cost.

Table 3. Regression Result for The Average Variable Cost per Student for RTVUs at Prefecture and City Level

\begin{tabular}{ccccc}
\hline \multirow{2}{*}{ Variables } & \multicolumn{4}{c}{ Regression coefficient (t-Statistic) } \\
\cline { 2 - 5 } & National & Fujian & Hunan & Xianjiang \\
\hline Intercept & $3463628(4544102)^{* * *}$ & $26582287(3892756)^{*}$ & $468.7471(2.551921)^{*}$ & $239.6621(2.387278)^{*}$ \\
Enrolled St Number & $0.046015(3.936580)^{* *}$ & $0.029315(3.147089)^{* *}$ & $0.079042(2.723158)^{* *}$ & $0.137426(2438192)^{* *}$ \\
R-squared & 0158196 & 0.209822 & 0.254204 & 0.792192 \\
Adjusted & 0.147930 & 0.189028 & 0.220304 & 0.717974 \\
R-squared & & & & \\
F-statistic & 15.40898 & 10.09034 & 7.498671 & 10.67396 \\
Prob (F-statistic) & 0.000179 & 0.002956 & 0.011997 & 0.000221 \\
Hausman & Chi-Sq.Statistic=1 & Chi-Sq.Statistic=0 & Chi-Sq.Statistic=0 & Chi-Sq.Statistic=1 \\
Test & 461752 & 298538 & 756249 & 366253 \\
& Prob.=0.2267 & Prob. $=0.5848$ & Prob. $=0.385$ & Prob. $=0.0205$ \\
Method & random & random & random & fixed \\
\hline
\end{tabular}

Notes: a. "significance <.05; ** significance <.01; ** significance $<.001$

b. unit cost in the regression is $10 \mathrm{~K}$ Yuan

c. original cost data

d. unchanged price $=100 \times$ current year cost/local CPI 
Table 4. Regression Result for The Average Variable Cost per Student for RTVUs at Prefecture and City Level

\begin{tabular}{|c|c|c|c|c|}
\hline \multirow{2}{*}{ Variables } & \multicolumn{4}{|c|}{ Regression coefficient (t-Statistic) } \\
\hline & National & Fujian & Hunan & Xianjiang \\
\hline Intercept & $259.7721(4.544102)^{\star \star \star}$ & $199.3715(3.892756)^{\star \star \star}$ & $351.5603(2.551921)^{\star}$ & $179.7466(2.38278)^{*}$ \\
\hline $\begin{array}{l}\text { Enrolled St } \\
\text { Number }\end{array}$ & $0.034512(3.936580)^{\star * *}$ & $0.021986(3.147089)^{* *}$ & $0.059311(2.723158)^{*}$ & $0.103069(2.438192)^{*}$ \\
\hline R-squared & 0158196 & 0.209822 & 0.254204 & 0.792192 \\
\hline $\begin{array}{l}\text { Adjusted } \\
\text { R-squared }\end{array}$ & 0.147930 & 0.189028 & 0.220304 & 0.717974 \\
\hline F-statistic & 15.40898 & 10.09034 & 7.498671 & 10.67396 \\
\hline $\begin{array}{c}\text { Prob } \\
\text { (F-statistic) }\end{array}$ & 0.000179 & 0.002956 & 0.011997 & 0.000221 \\
\hline $\begin{array}{l}\text { Hausman } \\
\text { Test } \\
\text { Method }\end{array}$ & $\begin{array}{c}\text { Chi-Sq.Statistic=1 } \\
461752 \\
\text { Prob. }=0.2267 \\
\text { random }\end{array}$ & $\begin{array}{c}\text { Chi-Sq.Statistic }=0 \\
298538 \\
\text { Prob. }=0.5848 \\
\text { random }\end{array}$ & $\begin{array}{c}\text { Chi-Sq.Statistic=0 } \\
756249 \\
\text { Prob. }=0.385 \\
\text { random }\end{array}$ & $\begin{array}{c}\text { Chi-Sq.Statistic=1 } \\
366253 \\
\text { Prob. }=0.0205 \\
\text { fixed }\end{array}$ \\
\hline
\end{tabular}

Note: $\quad$ a. * ${ }^{*}$ significance $<.05 ;{ }^{* *}$ significance $<.01 ;{ }^{* *}$ significance $<.001$

b. unit cost in the regression is $10 \mathrm{~K}$ Yuan

c. adjusted costing data by coefficient (0.75)

d. unchanged price $=100 \times$ current year cost/local CPI

Table 3 describes that average variable cost per students may varies in locations at different economic development level; the basic tendency is that variable cost per students in the east is lower than that in the central part, and highest in the west. Table 4 is the findings of regression on variable cost per students in RTVUs at prefecture and city level based on the adjusted data by coefficient. And the situation is similar to that in Table 3 . The average variable cost per students is as follows: (national) 345, Fujian 220, Hunan 593, and Xinjiang 1.031.

\section{The Analysis on the Scale Economy for RTVUs at Prefecture and City Level and The Optimal Scale in Student Number}

In case of other conditions have been controlled, there is a scale economy for ODL in RTVUs at prefecture and city level, i. e. with the increasing number of students, the average cost per student decline. The conclusion applies to both national and provincial samples see Table 5 (original data table) and Table 6 (adjusted original data by coefficient).

According to regression model results, the enrolled student number at $U$ shaped curve to keep the lowest average cost per student has been further worked out.

(1) Original data: from the perspective of nationwide, according to $U$ shaped curve regression result: for RTVUs at prefecture and city level, when the enrolled students number equals 7,837 , the average cost per students is the lowest: when enrolled students number is more that, 7,837 , with the increasing number of enrolled students, the average cost per student goes up. That is to say, the optimal scale in student number for RTVUs at prefecture and city level is 7,837. From results of provincial samples analysis, the optimal 
scale in student number for Fujian, Hunan and Xinjiang are: 9129, 3855, and 2212 respectively. Comparing with Table 1 showing the average scale in enrolled student number, there is big room for increasing the enrolment of students in RTVUs at prefecture and city level in the east, while there is still room for expansion in RTVUs at prefecture and city level in the central and western areas, however, the room for expansion is much smaller than that in the east. From Table 5, from nationwide perspective, it is also noticed that the ratio between student and teachers has a significant effect on the average cost per student, and it is negative, i.e. if the students and teachers ratio is high, the average cost per student will down. The tendency basically reflects teaching mode in RTVUs at prefecture and city level-self-access learning based on multi-media. However, from the perspective of provincial samples, the impact of ratio between students and teachers on average cost per students is not significant. That phenomenon may result from the less provincial samples than those in nationwide analysis,

(2) Original costing data adjusted by coefficient: the results of calculation of adjusted cost by coefficient demonstrate: the optimal scale in enrolled student number in RTVUs at prefecture and city level nationwide is 7833 . The results of provincial samples analysis is as follows: the optimal scale in enrolled student number far Fujian is 9129,3852 for Hunan, and 2212 for Xinjiang, The above results are very close to the results from original data.

Table 5. Estimated Results for the Analysis on the Scale Economy of RTVUs at Prefecture and City Level

\begin{tabular}{|c|c|c|c|c|}
\hline \multirow{2}{*}{ Variables } & \multicolumn{4}{|c|}{ U Shaped (t-statistics) } \\
\hline & Nationwide & Nationwide & Fujian & Hunan \\
\hline \multirow[t]{2}{*}{ Enrolled St Number } & -0779092 & -0.555048 & -4.479582 & -9.394680 \\
\hline & $(-4.178833)^{\star * *}$ & $(-5.445197)^{\star * *}$ & $(-4.201364)^{* * *}$ & $(-5.920911)^{\star * *}$ \\
\hline \multirow{2}{*}{$\begin{array}{l}\text { Square of enrolled } \\
\text { students number }\end{array}$} & 4.97E-05 & 3.04E-05 & 0.000581 & 0.002123 \\
\hline & $(3.240568)^{* *}$ & (3.667262) & (3.390468) & $(4.898520)$ \\
\hline \multirow{2}{*}{$\begin{array}{c}\text { Ratio between students } \\
\text { and teachers }\end{array}$} & -14.99015 & -8.249869 & 2.612661 & 0.002123 \\
\hline & $(-2.128598)^{*}$ & $(-2.001070)$ & (3.390468) & $(4.895520)$ \\
\hline $\begin{array}{l}\text { Dummy variables in } \\
\text { East China }\end{array}$ & $-519.8220(-1.188961)$ & - & - & - \\
\hline $\begin{array}{l}\text { Dummy variables in } \\
\text { Mid China }\end{array}$ & $897.0043(1.923173)$ & - & - & - \\
\hline \multirow[t]{2}{*}{ Intercept } & 4553.341 & 3370.077 & 9517.423 & 12299.17 \\
\hline & $(11.26444)^{* * *}$ & $(13.97083)^{* * *}$ & $(7.301773)^{\star * *}$ & $(10.85228)^{* * *}$ \\
\hline R-squared & 0.493311 & 0.726069 & 0.855525 & 0.834257 \\
\hline Adjusted R-Squared & 0.460831 & 0.703241 & 0.778472 & 0.803180 \\
\hline F-statistic & 15.18813 & 31.80664 & 11.10302 & 26.84503 \\
\hline Prob(F-statistic) & 0.000000 & 0.000000 & 0.000047 & 0.000002 \\
\hline Method & random & random & fixed & random \\
\hline
\end{tabular}

Notes: a. "significance <.05; ** significance <.01; ** significance <.001

b. method: determined by Hausman Test Prob.

c. original costing data

d. unchanged price $=100 *$ current year cost/local CPI 
Table 6. Estimated Results for the Analysis on the Scale Economy of RTVUs at Prefecture and City Level

\begin{tabular}{ccccc}
\hline \multirow{2}{*}{ Variables } & \multicolumn{4}{c}{ U Shaped (t-statistics) } \\
\cline { 2 - 5 } & Nationwide & Nationwide & Fujian & Hunan \\
\hline Enrolled students & -0.584319 & -0.416286 & -3.359686 & -7.046010 \\
Number & $(-4.178833)^{* * *}$ & $(-5.445197)^{* * *}$ & $(-4.201364)^{* * *}$ & $(-5.920911)^{* * *}$ \\
Square of enrolled & $3.73 \mathrm{E}-05$ & $2.28 \mathrm{E}-05$ & 0.000436 & 0.001592 \\
students number & $(3.240568)^{* *}$ & $(3.667262)$ & $(3.390468)$ & $(4.898520)$ \\
Ratio between & -11.24261 & -6.187402 & 1.959495 & -4.209985 \\
students and & $(-2.128598)^{*}$ & $(-2.001070)$ & $(3.390468)$ & $(4.895520)$ \\
teachers & & & & \\
Dummy variables in & $-389.8665(-$ & - & - & - \\
East China & $1.188961)$ & & - & - \\
Dummy variables in & $672.7532(1.923173)$ & - & & \\
Mid China & & & & \\
Intercept & 3415.006 & 2527.557 & 7138.068 & 9224.379 \\
& $(11.26444)^{* * *}$ & $(13.97083)^{* * *}$ & $(7.301773)^{* * *}$ & $(10.85228)^{* * *}$ \\
R-squared & 0.493311 & 0.726069 & 0.855525 & 0.834257 \\
Adjusted R- & 0.460831 & 0.703241 & 0.778472 & 0.803180 \\
Squared & & & & \\
F-statistic & 15.18813 & 31.80664 & 11.10302 & 26.84503 \\
Prob(F-statistic) & 0.000000 & 0.000000 & 0.000047 & 0.000002 \\
Method & random & random & fixed & random \\
\hline
\end{tabular}

Notes: a. ${ }^{*}$ significance $<.05$; * ${ }^{*}$ significance $<.01 ;{ }^{* *}$ significance $<.001$

b. method: determined by Hausman Test Prob.

c. original costing data by coefficient (coefficient $=0.75$ )

d. unchanged price $=100^{*}$ current year cost/local CPI

There are some other findings of the empirical study. The rise in ratio between students and teacher will result in a fall in average cost per student. Generally speaking, ratio between students and teachers is an important variable for reflecting teaching and service quality. Consequently, when the expansion of ODL contributes to a fall in average cost per student, the impact on educational inputs for teaching quality shall not be neglected. When we review the scale economy in teaching venues, how to balance the relationship among scale, quality and effectiveness shall be future taken into account.

First of all, the precondition of realizing scale economy is the expansion of quality teaching resources. The fall in average cost per students rely on the allocation of fixed cost for more enrolled students, that is, the sale in student number shall be further expanded. That will make it possible for us to share the benefit of scale economy. Whereas, the control for marginal cost (Zhang, 2006) and further improvement is teaching resources arc the precondition for us to share benefit. The definition of marginal cost is the change in total cost that arises when the quantity produced changes by one unit. The result is a marginal increment from total output. In such a concept, the marginal cost for a newly recruited student is the extra expenditure caused by the new student. It is expected that the increment in scale and effectiveness can be kept in the same pace. In fact, there are three possible relationships among scale, average cost and marginal cost--relatively economical, not economical and no changes in effectiveness. Ratio between fixed cost and variable cost and proper use of educational resources really matter the 
relationship mentioned above. There is a logical starting point in theory for designing ODL mode when classifying fixed cost (Zhang \& Wang, 2005). Separation between teachers and students has been taken into account for ODL planning. The geographical distance between teachers and students has to be bridged via teaching media to the precondition of students having access-learning ability. As a result, to give priority to quality educational resources is the precondition and basis for extending distance education. There is no direct linkage between the preliminary input and student numbers and the cost only can be shared by future expansion in scale. In other words, improving the quality of reaching media resources is an essential guarantee if we hope to continuously share the benefit of scale economy.

Secondly, analyzing the impact of the ratio between student and teacher on scale and effectiveness in an objective perspective should be accorded to local condition and strategic planning. Both effectiveness and quality can be reflected by ratio between student and teacher. The low and high ratio between student and teacher is in a close connection with teaching mode (Zhang, 2006), and it brings about a deep impact on average cost per student. It can be seen from the survey: in the past, in some local teaching venues, the enrolled student numbers were around $10 \mathrm{~K}$ and there was a high ratio between student \& teacher and a low average cost per student. It seems that those RTVUs fully enjoy the benefit from scale economy, improve their financial position, and it enable them to make a new investment planning. However, how to figure out the direction of investment to keep the balance of quality, cost and effectiveness? As a RTVU, to keep economic growth, sustain and strengthen input for scale economy is the first choice. The input for renewable educational shall be focus, such as input for excellent courses resource construction, students' question resource database construction, technical platform establishment and etc, which not only benefit distance learners but also minimize marginal cost caused to new students. But, there is a key issue existing in the input, such as, when turning RTUVs' reserve into construction of campus-including purchasing more land, more offer buildings and campus facilities, providing direct on-campus service to mould university image. Although all those measures are necessary and undoubted, the key issue is-how to handle the 'extent'? Utilization efficiency of costs shall be taken into full consideration (Fang, Zhang, \& Zhang, 2007), control for average cost per students shall be reviewed, the role of university shall be future clarified, whether sticking to the scale economy mode with a low cost or in pursuit of facility input with a high operating cost or not shall he decided. As a running school entity, a RTVU cannot avoid the above obstacles.

Thirdly, the investment for quality assurance of ODL shall be increased to keep the pace of pursuing scale economy. During the research, there is a significant impact of investment for educational quality on average cost per student, that is, a drop of average cost per student may he at the expense of lowering education quality. It's a warning that the service quality for the increasing student number in the process of learning cannot be neglected, although we have chosen the multi-media hosed ODL mode to share benefits from scale economy, and it demand for service may arise. Theoretically speaking, the formation of scale economy for ODL is a self-contained distance learning mode, which is focusing on self-study, and based on well planned and designed learning package. Interaction between teaching and learning has been integrated into teaching materials; dialogue between teachers and students has turned into interaction between human and computers, which relatively reduce teaching operating cost. 
Actually, teaching issues never come to an end even with the preliminary planning. Learning is like 'He who does not advance loses ground' and taking personal efforts. Furthermore, during learning process, university shall take good care of learners and encourage, review, examine, and mobilize them to study. There will he a diversified demand for service with the expansion of scale, and necessary management cost service cost cannot be reduced. Teaching quality cannot be assured if we do not pay attention to learning process management and teaching service. To let learners to study all by themselves will make universities less influential in learning process. In the final analysis, we have to keep the dynamic balance among distance quality, scale and effectiveness.

Finally, there are two question deserving more attention when understand mg the research findings. (1) When doing research on the effectiveness of distance education, it is usual for researchers to suppose that the conventional education and ODL have the same education quality in education effect, in such a hypothesis, the effectiveness of running-school for ODL are discussed. However, this hypothesis is very weak in reality. Carnoy and Levin (Carnoy \& Levin, 1975) pointed out that advantage of open university for cot saving has to deducted by a small portion of education output. They also pointed out that the conventional university students, compared with open university students, have received a lot of valuable services such us the communication with classmates, library service, and campus lecture, etc. (2) Compared with conventional education, ODL has a relatively higher drop-out rate, or we call it dormancy rate, which is the fact for ODL without argument. The high drop-out rate or dormancy rate, to some extent, has increased the average cost per student in ODL institutions. The average cost per student calculated from the selected data in this research paper has not been adjusted according to drop-out rate or dormancy rate. The two questions mentioned above need further research.

\section{CONCLUSION}

This article has analyzed the scale economy for ODL in RTVUs teaching venues at prefecture and city level in the aspect of cost per student, the average variable cost per student, scale economy and optimal scale of student number, etc with the consideration of the gaps of economy development in the different parts of China. The major analysis result has shown:

With the expansion in enrolled student number, the average cost per student for RTVUs at prefecture and city level has decline, consequently, there is a scale economy existing in teaching venues in RTVUs at prefecture and city level. The enrolled student numbers in RTVUs at prefecture and city level in Fujian is higher than those in Hunan, and Xinjiang has the smallest number of entrants. For average cost per students, RTVUs at prefecture and city level in Fujian is the lowest, while, the average cost per student in Hunan and Xinjiang are close to each other.

There is still a big gap between the average variable cost per student and the average cost per student of RTVUs at prefecture and city level, there is still room for cost reduction in the current teaching mode of RTVUs at prefecture and city level. The average variable cost per student varies in areas at different development level. The basic trend is-average variable cost 
per student in the east is lower than that in the central part, and the central part is lower than the western part.

In the hypothesis of other condition under control, the average cost per student in ODL has a characteristic of scale economy. From nationwide, the optimal scale in enrolled student number is around 7800 , from provincial sample analysis, the optimal scale in enrolled student number in RTVUs at prefecture and city level is Fujian 9100, Hunan 3800, and Xinjiang 2200. Compared with current average scale in enrolled student number among RTVUs, there is big room for expansion for RTVUs at prefecture and city level in the east with good local condition, RTVUs at prefecture and city level in the middle and west are still potential for expansion, but there is smaller room for expansion compared with the east.

From the regional analysis, the findings of the empirical study also reflect that imbalances of development of RTVUs at prefecture and city level due to at different geographical economic location and economic development levels.

\section{REFERENCES}

CCRTV. (2007). Development and planning office of CCRTV, statistic report on basic educational situation in RTVUs of 2007. distance education in China, 62-65.

Wagner, L. (1972). The economic of the open university, higher education, 1 (2), 159-83.

Wagner, L. (1973). The economic of the open university: A reply, higher education, 1 (2), 71 72.

Wagner, L. (1977). The economic of the open university revisited, higher education, 6 (3), 359381.

Rumble, G. (1997). The costs and economics of open and distance learning, open university. London, Stirling (USA).

Rumble, G. (1976). The economic of the open university. Paper presented to the Anglian Regional Management College/Organization for Economic Co-operation and Development, International Management Development Programme for Senior Administrators in Institutions of Higher Education, Danbury, Essex, 1976-1967. Open University, Academic Planning Office, Milton Keynes.

Xing Yi. (1988). Great prospective for satellite TV based education-congratulations for the 2year-anniversary of educational TV broadcasting in China.

Ding Xingfu. (1990). The evaluation on the education quality and investment benefit for China RTVUs. Wuhan: Wuhan Publishing House.

Wu Gengsheng Li Haixia. (2005). The analysis and comparison of the cost from online colleges-Tshingua University case study. China Distance Learning, (1), 23-26.

Zheng Qinhua Chen Li (2004). The analysis on the cost of China modern distance learning network courses. Distance Learning and Network Education, (6), 30-35.

Yang Tingting Yin Shuangxu (2007). The research on the comparison of network medias and other medias in the aspect of cost and applications. Jiangsu Radio and TV University Bulletin (1): 5-8.

Ding Xiaohao. (2000). Empirical research on the scale economy benefit for Chinese colleges and universities. Beijing: Education Science Publishing House. 
Zhang Shaogang (2006). Rise or fall for distance education cost with technology development? Modern Distance Education Research, (6), 5-9.

Zhang Shaogang, Wang Shujuan (2005). Digital learning \& effective reform on teaching time and space. Distance Education in China, (1): 12-14.

Fang Zichun, Zhang Xuhong, Zhang Shaogang. (2007). Analysis on cost-effectiveness in ODL. Modern Distance Education Research, (6):11-14.

Carnoy, M \& Levin, H (1975). Evaluation of educational media: Some issues. Inst.Sci.4 (3/4), 385-406. 